\title{
Dva soubory studií o Janu Husovi vydané v Polsku
}

Před časem jsme se na stránkách tohoto časopisu ohlíželi za jubilejním rokem 2015 a jeho produkcí husovských publikací. ${ }^{1}$ Nebylo možné probrat vše do posledního titulu, a navíc některé vyšly s malým zpožděním. ${ }^{2}$ Vracíme se proto na tomto místě alespoň ke dvěma sborníkům, které přinesly hodně zajímavého, a neměly by proto uniknout pozornosti české odborné scény.

Gdaňská univerzita a tamější evangelická církev vydaly v roce 2016 soubor statí ${ }^{3}$ polských i českých historiků, které většinou shrnují různá témata spjatá s osobou Jana Husa. Polskému čtenáři může tato publikace sloužit jako výchozí bod pro orientaci v husovské problematice. Získá zde přehled o politické a ideologické krizi doby Václava IV. (Anna Paner), vývoji představ o reformě církve od Valdese po Matěje z Janova (Wojciech Gajewski), proměnách vztahu krále Vladislava Jagiella k husitským Čechám (Jerzy Sperka), stejně jako o př́stupech římské církve k husitské problematice až do doby Jiřího z Poděbrad (Janusz Smołucha). Př́mo postavě Jana Husa, jeho názorům a ohlasům je věnováno sedm studií.

Martin Nodl stručně shrnuje peripetie vztahu Husa a pražské univerzity, téma, které již zaujalo více autorů. Nodl se ale na tomto místě omezuje jen na vlastní námět bez reflexe starších prací. Jinou stránku Husovy osobnosti probírá Petr Čornej ve stati nazvané Homo politicus. Jedná se o výborně formulovaný pohled na Husovo politické angažmá zvláště v letech 1402-1410. Úvahu o kolísání představ o Husovi jako světci nebo kacírí podal Jerzy Grygiel. Další dva př́ispěvky sledují reálnou, respektive virtuální přítomnost Husa na jednáních koncilu v Kostnici (Wojciech Iwańczak) a v Basileji, kde se jeho kauza odráží v polemikách a jednáních koncilu s husity (Paweł F. Nowakowski). Autor se zaměřil na basilejské vystoupení Mikuláše Biskupce. Poslední dvě stati se věnují vztahu Jana Husa a Martina Luthera. Marcin Hintz zdůrazňuje, že je sice Hus vnímán jako preludium k vystoupení M. Luthera, návaznost jejich historických rolí však nespočívá v kontinuitě jejich teologických představ. Luther přijal Husa jen výběrově a vizi nápravy církve formuloval odlišně. Jerzy Sojka soustředil své srovnání obou reformátorů pouze na otázku definice církve, jak ji Hus formuloval v traktátu De ecclesia a Luther v několika svých spisech.

Gdaňský sborník jistě přispěje k rozšiřování povědomí o místě Jana Husa v evropských dějinách konce středověku. Badatelsky nenabízí výrazné výboje, řada úvah ale může být

1 Blanka ZiLYNSKÁ, Literární sklizeň husovského jubilejního roku 2015, AUC-HUCP 55/2, 2015, s. $133-145$.

2 Nové tituly vycházejí i nadále. Vloni vydanou dánskou biografii o Janu Husovi představil Vít MišAGA, Hus na severu, Dějiny a současnost 41/5, 2019, s. 34-35. Jedná se o knihu: Peter Tudvad, Jan Hus. Kirke - Korstog - Kaetteri, Kodaň 2018, 336 s. Zároveň referent přináší přehled rozsáhlé recenzní produkce, kterou kniha v Dánsku vyvolala. Kniha ovšem nebyla ,jedním z nemnoha zahraničních ohlasů nedávného výročí upálení Jana Husa“, jak míní Mišaga, je to patrné z výčtu zahraničních publikací ve výše uvedeném referátu a z dále popsaných publikací.

3 Anna PAner - Marcin Hintz (edd.), Jan Hus. Życie i dzieło. W 600. rocznicé śmierci, Gdańsk 2016,199 s., ISBN 978-83-7865-611-1. 
kvalitním př́ispěvkem do diskusí vedených kolem různých otázek Husova života, postojů a názorů.

Druhá, objemnější publikace ${ }^{4}$ vyšla ve Varšavě a je výstupem konference, která se odehrála tamtéž v roce 2015. Knížka je věnována prof. Stanisławu Bylinovi († 2017), jenž se konference účastnil a s nímž byl koncem roku 2016 pořízen rozhovor, bohužel nedokončený, který je ve svazku otištěn. Publikaci otevírá úvod Wojciecha Kriegseisena, věnovaný $\mathrm{Z}$ velké části památce $\mathrm{S}$. Byliny. Vstupní př́spěvek vědeckých redaktorů svazku, Pawła Krase a Martina Nodla, shrnuje pro polského čtenáře základní údaje o životě a díle Jana Husa. Ve druhé části se pak věnují husovské historiografii, respektive některým jejím stránkám. Prostoru se dostalo J. Loserthovi, jehož zkoumání Husovy závislosti na Wyclifovi je zde podáno s větší přesností a pochopením oproti starším interpretacím. Druhým zájmovým bodem autorů byla česká katolická historiografie zabývající se Husem, na jejíž specifika poukazují, a přehled končí připomenutím katolického prostředí polského, z něhož vyšly impulzy pro úvahy o rehabilitaci Husa (S. Swieżawski). V závěru naznačují, že by sborník měl připravit cestu pro vznik originální polské životopisné monografie Husa.

Bilanční a historiografický charakter má i př́ispěvek Františka Šmahela, původně otištěný česky v jeho Husitských Čechách (2001) a posléze i německy (Konstanzer Universitätsreden 2007), v polské verzi s mírně doplněným poznámkovým aparátem. Hus a Jeroným před soudem koncilu a dějin je zamyšlení zkušeného historika nad osudy dvou postav, jimž věnoval své badatelské úsilí. $Z$ úvah nad motivacemi jejich činů a interpretacemi jejich krokủ a výroků je patrné, jak hluboce autor promýšlel souvislosti, smysl a významy dějů, o nichž psal.

Do oblasti dějin historiografie patří ještě další dva př́spěvky. Jarosław Nikodem chtěl představit Husa v pojetí Jiř́iho Kejře. Výsledkem ovšem není ani Kejřův portrét kazatele, ani vyhodnocení Kejřova př́nosu k husovskému bádání. Autor se omezil na obsáhlejší citáty či reprodukce názorů, které místo celistvého obrazu vytvářejí jen nehodnotící mozaiku výroků a témat Kejřem dotčených. Úspěšnější byl Wojciech Iwańczak při své snaze ukázat vývoj názorů polského bohemisty Romana Hecka na husitskou epochu. Autor oceňuje některé oblasti jeho výzkumu, ale přiznává, že řada jeho soudů determinovaných dobovým marxistickým diskurzem je dnes již antikvována. Tady postrádáme konkrétnější pojmenování těchto témat. Spadá sem snad otázka národního a slovanského vědomí, kde mohla při hodnocení pomoci komparace např. s výzkumy F. Šmahela nebo P. Čorneje.

Dalším tematickým celkem je kazatelství. Krzysztof Bracha se věnoval všestranně kazatelství Jana Husa a jeho požadavkům na kazatele i názorům na úlohu kazatele, včetně otázky účinnosti působení nehodného kněze. Význam kázání jako prostředku evangelizace byl zdůrazňován již Husovými předchůdci a on sám i jeho stoupenci je cenili co do účinku na věřící dokonce nad mši. Kázání bylo pro Husa povinností, kterou musí kněz plnit jako následník Krista. Pavel Soukup si položil specifičtější otázku: Jak naplnil Hus sám tuto kazatelskou povinnost, kolik kázání pronesl za svůj aktivní život? Soukup reviduje informace o kazatelském provozu v Betlémě, o doložených osobách a povinnostech držitelů tamějších beneficií, aby konečně propočítal množství pravděpodobných kázání Husa. Výsledné číslo konfrontoval s jeho dochovanými texty. Dostal se na sumu cca 3000 pronesených a 1160 dochovaných kazatelských projevů.

4 Paweł Kras - Martin Nodl (edd.), Jan Hus. Życie, myśl, dziedzictwo, Instytut Historii PAN, Warszawa 2017, 337 s., ISBN 978-83-65880-09-3. 
Další autoři podávají analýzu některé z otázek Husovy nauky. Pavlína Cermanová sledovala nebiblická proroctví v Husových spisech a vyhodnotila, které texty mohl znát, i způsob jejich užití. Husovy názory na manželství a rodinu zpracovala Anna Paner. Klíčovým pojmem Husova učení je však především pojetí církve.

Na toto téma bylo už vydáno mnoho studií. Ve sledovaném svazku se ho týkají hned dvě. Paweł Kras podal rozsáhlý přehled tématu reformy církve, jak je navrhována u Viklefa a Husa. Pro polského čtenáře, a nejen pro něho, je to zásadní, dobře orientovaný přehled s početnými citáty z děl obou reformátorů. Martin Nodl se zamýšlí nad možností uplatnění Husovy představy církve predestinovaných v pozemské realitě a zkoumá, jakou odezvu mělo Husovo pojetí u dalších autorů husitské epochy.

Husovu predestinační teorii nenásledoval Jakoubek ze Stř́ibra, jemuž věnoval pozornost Dušan Coufal. Jeho východiskem byla Jakoubkova dosud nevydaná kvestie o koncilech. Coufal k ní představil široký kontext doby vzniku na jedné straně a na straně druhé přehled dobových znalostí o koncilech. Z jeho analýzy plyne, že Jakoubek i jeho druhové přistupovali ke koncilům historicky a pragmaticky. Výsledkem bylo převážně míjení evropského konciliaristického proudu a kritické vidění soudobých (podle Jakoubka fiktivních) koncilů, $\mathrm{z}$ nichž ten kostnický byl k husitům tak nepříznivý. Coufalova studie, jako u něho vždy založená na př́mém zpracování pramenů, je velmi hodnotným příspěvkem $\mathrm{k}$ tématu, které se v českém prostředí dosud nedočkalo dostatečné pozornosti.

Za tematický závěr svazku můžeme považovat př́spěvek Henryka Gmiterka o husovské a husitské tradici v polské Jednotě bratrské. Vedle připomenutí počátků Jednoty sleduje osudy její polské větve a míru připomínání Husa do konce 16. století.

Varšavský sborník nabízí vedle shrnujících příspěvků i několik badatelsky přínosných studií. Řadí se nepochybně k těm zdařilejším publikacím, jejichž vznik podnítilo husovské kulaté jubileum.

Blanka Zilynská

doi: $10.14712 / 23365730.2019 .23$

\section{Dominik Opatrný, Zachránit lidi od hříchů. Etika v teologii mistra Jana Husa} Jan Keřkovský - Mlýn, Jihlava 2018, 128 s., ISBN 978-80-86498-65-2

Nedávné kulaté výročí smrti Jana Husa vyvolalo v život mnoho publikací o něm, většinou shrnujících a bilančních. Nové badatelské výkony se objevují spíše výjimečně a dodatečně. Patř́ mezi ně i studie D. Opatrného. Jeho práce se věnuje různým otázkám z oboru etiky, viděným zorným úhlem spisů M. J. Husa.

První kapitola načrtává jeho životopisná data a hlavně představuje díla, v nichž lze příslušné myšlenky najít. Autor pracuje s texty editovanými v moderní formě i v edicích starobylých (od vydání z 16. stol.), do rukopisných textů nenahlížel. Pramenná základna je i tak dostatečně široká.

Vlastní analýza etické problematiky je rozdělena do devíti oddílů, které sledují jednotlivá témata Husovy etiky. Hus ovšem nezanechal spis věnovaný speciálně a soustavně morálnímu učení. Opatrný proto musel sestavit Husovy názory rozptýlené v různých dílech do logické struktury. Vycházel ze spisů, které bud' obsahují v tomto směru rozsáhlejší pasáže (např. O postačitelnosti zákona Kristova), nebo jen jednotlivé a dílčí výroky. 